\title{
ICT ADOPTION AND USE IN TANZANIA SMES
}

\author{
Cuthbert A. Msuya ${ }^{1 *}$, Emanuel A. M. Mjema ${ }^{2}$, Beatus A. T. Kundi ${ }^{3}$ \\ ${ }^{1}$ Training Workshops Department, College of Engineering and Technology, \\ University of Dar es Salaam,P.O. Box 35131, Dar es Salaam. \\ *Corresponding author: amomsuya@udsm.ac.tz \\ ${ }^{2}$ College of Business Education (CBE) \\ P.O. Box 1968, Dar es Salaam
${ }^{3}$ Department of Mechanical and Industrial Engineering, College of Engineering and Technology, University of Dar es Salaam, P.O. Box 35131, Dar es Salaam

\begin{abstract}
The purpose of this paper was to establish the status of ICTs adoption and use in Tanzania SMEs. Previously, it was shown that there is a shortage of comprehensive, accurate and up to date data on many aspects of the SMEs sector including the level of ICT adoption and use. This has affected government efforts aimed at development of this important sector in the economic development of the country. Results show that: (i) By year 2014, adoption of ICTs in SMEs had grown from almost non-existence in year 2004 to $80.1 \%$ computer technology use, and over 56.6\% for use of internet technologies; (ii) More than 53\% of the SMEs were using ICTs as a strategic communication and marketing tool; (iii) $47 \%$ of the SMEs were competitive due to use of ICTs. Given these results, the government and key stakeholders can formulate more effective policies and incentives aimed at developing the SME sector. Further research is recommended to address post adoption competitiveness issues.
\end{abstract}

Key Words: ICT Adoption, SMEs, Competitiveness, Tanzania

\section{INTRODUCTION}

In the past two decades, the use of Information and Communication Technologies (ICTs) in Small and Medium Scale Enterprise (SMEs) has been the focus of intense research (Costello, 2009; Modimongale, 2009; Apulu, 2012). This has been caused by the importance SMEs and ICTs have in the economic development of countries. While SMEs are recognised as the cornerstone of many economies, (URT, 2002; Kartiwi and MacGregor, 2007; EU, 2014), ICTs are credited with giving SMEs and indeed all business worldwide the ability to become efficient, innovative and competitive (UN
2007; Modimongale, 2009; Apulu, 2012; EU, 2014).

Based on these facts, governments and individual firms around the world are continually looking at the issue of increasing efficient adoption and use of ICTs in SMEs as a means of achieving economic development (Costello, 2009; Ahmed et al., 2010; Apulu, 2012; Consoli, 2012). However, in order for governments and individual firms to be able to come out with effective policies and strategies that can increase efficient adoption of ICTs in SMEs, availability of credible and up to date data on the status of the SMEs sector is important. 
Previous research shows that, the SME sector in Tanzania is besieged with a number of serious problems (NISS, 1991; Mlingi, 2000; URT, 2002; Mbamba, 2004; Olomi, 2005; Olomi, 2006; URT, 2012). To begin with, the authors noted that there is a shortage of comprehensive, accurate and up to date data on the state of the sector. According to Olomi, (2006), since year 1992, most reports on the sector have relied on the data from 1991 National Informal Sector Survey (NISS) which became outdated and unreliable as time went by. This observation suggests that, some if not all of the policies and strategies aimed at helping the SMEs sector might be flawed because they are based on unreliable outdated data. In addition, available literature shows that, despite numerous efforts by the government of Tanzania in developing the sector, the sector is still characterised by stagnant micro enterprises that have little incidence of growth (Olomi, 2006; URT, 2012). Moreover, while there is conclusive evidence that adoption and use of ICTs is critical to SMEs survival and growth (Costello, 2009; Modimongale, 2009; Ahmed et al., 2010; Harindranath et al., 2010; Skoko and Arnela, 2010; Apulu, 2012; Consoli, 2012; Naul, 2012; Olise et al., 2014; EU, 2014;Tarute and Gatautis, 2014) available literature show that, ICT adoption and use by Tanzania SMEs is very low (Jonathan, 2004; Mbamba, 2004; Muttayabalwa, 2007; Issaya, 2009; Naul, 2012; URT, 2012) and that SMEs in Tanzania are not utilising ICTs to their advantage (URT, 2012).

In view of these observations, the authors saw the need for a comprehensive study that provides up to date information on the status of ICT adoption and use by Tanzania SMEs. It is anticipated that, with accurate and up to date data, the government and policy makers can formulate more effective policies and incentives aimed at developing the SME sector. Thus, with the aim of establishing the status of ICT adoption and use by Tanzania SMEs, the research questions are:

- What is the status of ICT adoption by SMEs in Tanzania?

- What are the typical uses of ICTs in Tanzania SMEs?

- What is the post ICT adoption status of Tanzania SMEs?

\section{LITERATURE REVIEW}

\section{The SMEs}

The SMEs nomenclature is used to mean micro, small and medium enterprises (URT, 2002). Due to the wide diversity of businesses, there is no universally accepted definition of SMEs (Pass et al., 2000; Massawe 2003; Harindranath et al., 2010). Different countries use various measures of size depending on their level of development. The commonly used yardsticks are total number of employees, total investment and sales turnover (URT, 2002).

According to the literature (Kartiwi and MacGregor, 2007; Apulu, 2012; EU, 2014), almost $90 \%$ of the total numbers of businesses across the world are SMEs and they are considered the cornerstone of most economies. All over the world, SMEs play a significant role in creating employment opportunities and they contribute substantially to the GDP of many economies (Kartiwi and MacGregor, 2007; Apulu, 2012; EU, 2014). For example, The Observatory of European SMEs (2003), note that, in year 2003, about $92 \%$ of all European enterprises were SMEs. More recent data show that there are more than 20,000,000 SMEs in EU representing about $99 \%$ of all businesses (EU, 2014). These SMEs are considered to be the true back-bone of the European economy (EU, 2014). They are primarily responsible for innovation, employment, wealth generation, economic 
growth and social integration (EU, 2014). Available literature (Modimongale, 2009; Ahmed et al., 2010; Apulu, 2012) show the same trend in other area of the world. Apulu, (2012), note that, "SMEs are recognized as the main source of economic growth and a major factor in promoting private sector development and partnership, in developed and developing countries".

Available data show that, formal SMEs contribute up to $45 \%$ of employment and up to $33 \%$ of GDP in developing economies; these numbers are significantly higher when taking into account the estimated contributions of SMEs operating in the informal sector (International Finance Corporation, 2010). Literature (DBIS, 2013; International Finance Corporation, 2010) has also shown that in developing economies, SMEs could contribute more to economic development than they currently do. Given these observations Apulu (2010) concluded that, the SME sector cannot be ignored in the economic development of any country.

In Tanzania, the SME sector has been specifically recognised as a significant sector in employment creation, income generation, and poverty alleviation (URT, 2002; Mbamba, 2004; Olomi, 2005; Olomi, 2006; URT, 2012; NBS, 2014). Moreover, the sector is considered to be the backbone of industrial development in the country (URT, 2002; Mbamba, 2004; Olomi, 2005; Olomi, 2006; URT, 2012; NBS, 2014). According to URT, (2002), SMEs in Tanzania are defined as enterprise that has a capital investment on machinery in the range of Tanzanian Shillings (TShs). 5, 000,000 and TShs $800,000,000$ and/or employs up to 99 employees, with capital investment on machinery becoming the deciding factor in the event of an enterprise falling under more than one category. At present the SME sector contributes about $27 \%$ of the GDP and employs about $90 \%$ of new entrants into the labour market every year (URT, 2012). In view of this observation and the fact that Tanzania is characterised by low rate of capital formation, the government of Tanzania acknowledge that SMEs development remains to be the main source of jobs in the future (URT, 2002; Olomi, 2005; URT, 2012).

\section{The ICTs}

Information and Communication Technologies (ICT) is a broad concept that covers Information Systems (IS) Information Technology (IT) and digitalisation (Sophonthummapharn, 2008). According to Beckinsale and Ram (2006), ICT is "any technology used to support information gathering, processing, distribution and use" This covers all forms of technologies such as computers, internet, websites, fixed-line telephones, mobile phones and other wireless communications devices, computer networks, broadband and various specialised devices (Manueli et al., 2007). In the context of this paper, ICT referred to the use of computers and the Internet technology (connectivity, web technologies and email) in SMEs.

According to the literature (Ion and Andreea, 2008; Costello, 2009; Modimongale, 2009; Skoko and Arnela, 2010; Apulu, 2012), the advent of the ICTs in particular the internet and the world wide web has revolutionised the world in a remarkable way and for obvious reasons. The benefits of ICTs are many and they cut across all fields of human activities (Ion and Andreea, 2008; Costello, 2009; Modimongale, 2009; Skoko and Arnela, 2010; Apulu, 2012) including all sectors of the economy (Apulu, 2012). Apulu, (2010) note that, the use of ICTs in business has revolutionised business practices worldwide and this has made adoption and use of ICT critical to all business. She argues that, ICT implementations in 
business have become indispensable (Apulu, 2012).

In summary, available literature concludes that, in today's knowledge economy, the adoption and effective utilization of ICTs has become critical to all business survival and growth (Costello, 2009; Modimongale, 2009; Ahmed et al., 2010; Harindranath et al., 2010; Skoko and Arnela, 2010; Apulu, 2012; Consoli, 2012; Naul, 2012; Olise et al., 2014; EU, 2014; Tarute and Gatautis, 2014). In the same note, adoption and use of ICTs in SMEs have been shown to be a very effective way of improving the economic wellbeing of the country (Costello, 2009). However, it has also been shown that, due to their small size, SMEs generally lack in human as well as financial resources (Costello, 2009; Modimongale, 2009; Ahmed, et al., 2010; Harindranath et al., 2010; Skoko and Arnela, 2010; Apulu, 2012; Consoli, 2012; Naul, 2012; Olise et al., 2014; EU, 2014; Tarutè and Gatautis, 2014). Thus, adoption and effective use of ICTs in SMEs is not a straightforward issue.

\section{The Influence of ICTs in SMEs}

Harindranath et al. (2010) noted that, regardless of the differences that exist between big businesses and small businesses, SMEs are actually not different from larger firms in one key aspect. That is, in order to survive and prosper in competitive business arenas, both SMEs and larger firms need to successfully maintain a competitive advantage. Frempong (2007) and Apulu (2012) observed that, the contributions of ICT to business development have been allencompassing and therefore businesses of all size including SMEs find that without adequate ICT infrastructures, it is becoming increasingly difficult to compete effectively in the world markets (Frempong, 2007; Costello, 2009; Apulu, 2012).
Jannex et al. (2004) observed that, ICTs can increase the richness and reach of the SMEs. Using ICTs, SMEs get the opportunity to conduct business anywhere in the world (Jannex et al., 2004). Moreover, companies can communicate, collaborate and conduct transactions with their customers, distributors and suppliers via the internet (Evans and Wurster, 1997; Jannex et al., 2004). In other words, ICTs give SMEs the ability to participate in the global digital economy (Apulu, 2012). According to Ashrafi and Murtarza (2010), ICTs give SMEs the ability to gain access to new markets, supply new products and services, add value to products, changes the company business processes, increase performance and productivity of the business, give the ability to employ new business outlets and the ability to maintain competitiveness edge. According to the United Nations (2007), the use of ICT enables SMEs to participate in the knowledge economy and offers vast opportunities to narrow down the social and economic inequalities that will assist SMEs in achieving broader development goals (United Nations, 2007). More recent literature, (Modimongale, 2009; Ahmed et al., 2010; Harindranath et al., 2010; Skoko and Arnela, 2010; Apulu, 2012; Consoli, 2012; Olise et al., 2014; SMEs performance Review, 2014Tarute and Gatautis, 2014) conclude that, in today's knowledge economy, adoption and use of ICTs represents the fundamental source of competitiveness and the basis for SMEs survival and growth.

However, despite the recognition of the importance of ICTs in businesses, there is evidence to the effect that, SMEs particularly those in the least developed countries south of the Sahara Desert have not been responding quickly enough to changes in ICT (Mpofu, 2009; Harindranath et al., 2010; Apulu, 2012). That is, the take-up of such technologies by SMEs has not been widespread (Harindranath et al., 2010). This 
shortcoming has been a subject of intense research (including this work) in the past two decades. In addition, it has also been shown that, adoption of ICTs by firms does not necessarily give a firm competitive advantage. According to Modimogale, (2009), what ICT does is to give firms the ability to be competitive. In other words, competitiveness is a product of how the firms use ICTs.

The literature (OECD, 2005; Pavic et al., 2007; Modimogale, 2009; Apulu, 2012) shows that, SMEs can only attain a competitive advantage through process and product innovations, marketing, and better customer responsiveness. According to Costello, (2009), the advantages of ICTs such as competitiveness of SMEs actually depends on the way in which ICTs are used to support the business process. Thus, she recommends that ICTs should be adopted in order to support the business process. This study seeks to establish the status of ICT adoption and use by Tanzania SMEs. By knowing the level of adoption and how ICT are used post adoption, more targeted policies and strategies can be introduced to aid in the development of the sector.

\section{METHODOLOGY}

This study employed methodological triangulations involving multiple case studies and survey research strategies. The case studies provided qualitative data which was used in the design of a formal survey instrument. For the survey, using statistical methods and probabilistic sampling, the sample size was determined as 384 which were adjusted to 1000 samples in order to account for the nonrespondent error (Kripanont, 2007; Israel, 2013). Two stages sampling with regions making primary sampling units and districts making the secondary sampling units were used. In order to be able to generalise the results, probabilistic sampling was used in sampling of both primary and secondary units.

Data was collected from four major regions in mainland Tanzania namely Arusha, Dar es Salaam, Mbeya and Mwanza. Table 1 show the sample distribution prior to data collection. The owners-managers of SMEs were the unit of analysis. Overall, survey data from 599 SMEs was collected and analyzed. Out of the 1000 questionnaires distributed, 599 responses were collected, out of which, 194 questionnaires were rejected outright as they simply did not contain any meaningful data. The remaining 405 filled questionnaires could be used for one or more type of analyses and thus the initial response rate was $40.5 \%$. Further data cleaning resulted in a dataset with 341 samples. This was equivalent to a response rate of $34.3 \%$. Table 2 give a summary of collected survey data and the response rate.

\section{RESULTS}

\section{ICT Adoption}

The summary of ICT adoption in Tanzania SMEs is given in Figure 1. From the survey data it was observed that, $80.1 \%$ of the surveyed SMEs have adopted computer technology, $68.9 \%$ had a connection to the internet, $56.6 \%$ of the SMEs had websites while $72.7 \%$ had company emails. Prior to this study, available literature (Jonathan, 2004; Mbamba, 2004; Muttayabalwa, 2007; Souter et al., 2007; Issaya, 2009; Behitsa et al., 2010; Naul, 2012; URT, 2012) indicated that ICT adoption and use by Tanzania SMEs was less than $1 \%$. 
Table 1: Survey Sample Distribution

\begin{tabular}{|c|c|c|c|}
\hline Region & District & Sample Distribution & Sample Size (\%) \\
\hline \multirow[b]{2}{*}{ Arusha } & Arusha & 200 & 20 \\
\hline & Meru & 50 & 5 \\
\hline \multirow{3}{*}{ Dar es Salaam } & Ilala & 250 & 25 \\
\hline & Kinondoni & 150 & 15 \\
\hline & Temeke & 100 & 10 \\
\hline \multirow[t]{2}{*}{ Mbeya } & Mbeya & 100 & 10 \\
\hline & Nyamagana & 80 & 8 \\
\hline \multirow[t]{2}{*}{ Mwanza } & Ilemela & 20 & 2 \\
\hline & Sengerema & 50 & 5 \\
\hline \multicolumn{2}{|l|}{ Total } & 1000 & 100 \\
\hline
\end{tabular}

Table 2: Summary of collected Survey Data

\begin{tabular}{|l|r|r|r|r|c|}
\hline \multirow{2}{*}{ District } & Sample Size & \multicolumn{3}{|l|}{ Returned Questionnaires } & Response Rate \\
\cline { 2 - 5 } & & Used & Rejected & Total & $(\%)$ \\
\hline Arusha & 200 & 73 & 50 & 123 & 36.5 \\
Meru & 50 & 17 & 27 & 44 & 34.0 \\
\hline Ilala & 250 & 99 & 24 & 123 & 39.6 \\
\hline Kinondoni & 150 & 40 & 45 & 85 & 26.7 \\
\hline Temeke & 100 & 33 & 33 & 66 & 33.0 \\
\hline Mbeya & 100 & 8 & 11 & 19 & 8.0 \\
\hline Nyamagana & 80 & 39 & 43 & 82 & 48.8 \\
\hline Ilemela & 20 & 3 & 8 & 11 & 15.0 \\
\hline Sengerema & 50 & 31 & 15 & 46 & 62.0 \\
\hline Total & $\mathbf{1 0 0 0}$ & $\mathbf{3 4 3}$ & $\mathbf{2 5 6}$ & $\mathbf{5 9 9}$ & $\mathbf{3 4 . 3}$ \\
\hline
\end{tabular}

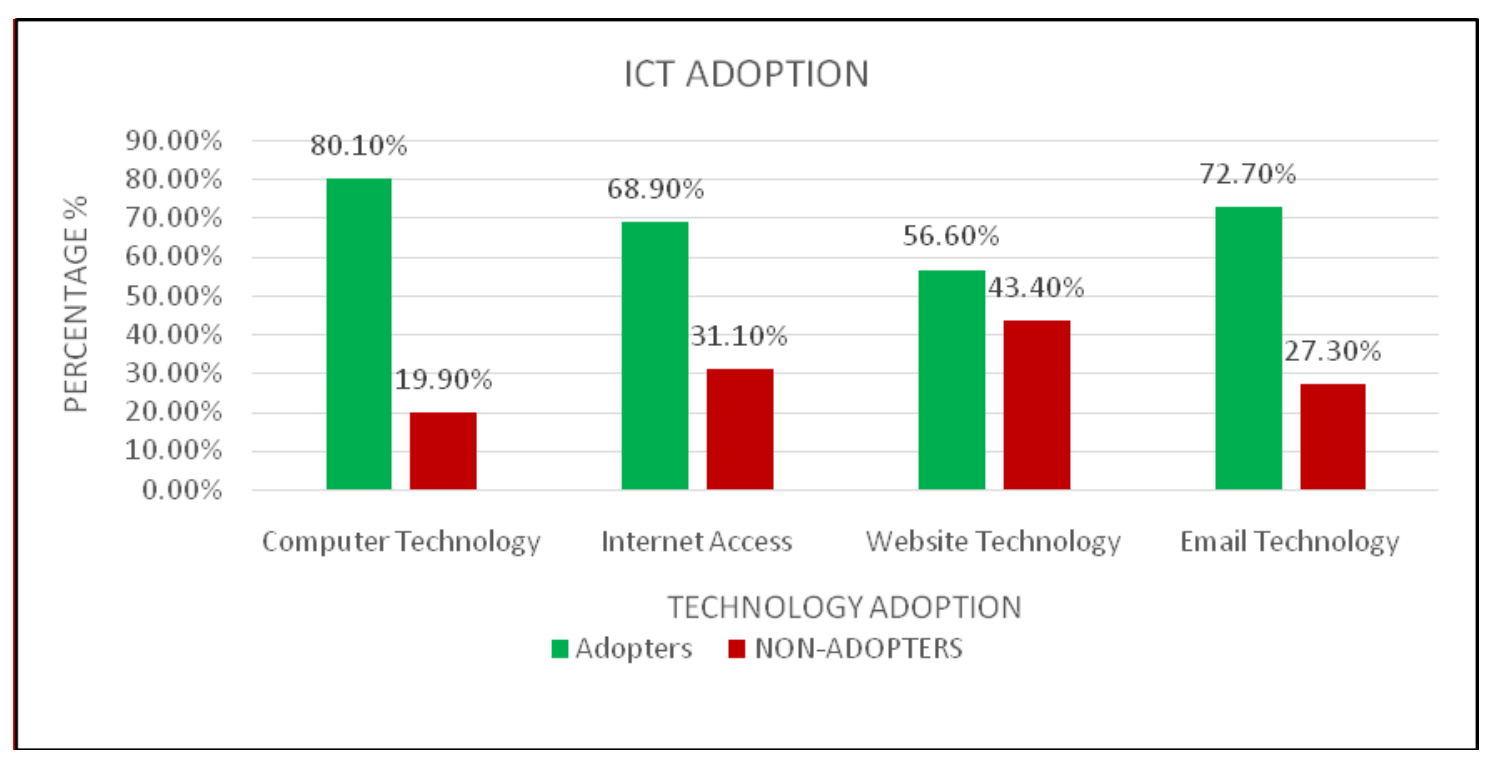

Figure 1: ICT Adoption in Tanzania SMEs 


\section{ICT Use}

The results on computer use are summarized in Figure 2. Survey results on the use of computers show that, $58.1 \%$ of surveyed firms use computers for all accounting activities. $52.8 \%$ firms use computers for market research. $44.9 \%$ of all surveyed firms claimed to use computers for all business transactions. The results on the Internet use are summarized in Figure3. Survey results for internet usage show that, $60 \%$ of the respondents use the internet (email) for external communications, $55.7 \%$ of respondents use the internet for obtaining information from suppliers, $52.2 \%$ of respondents use the internet for sending purchase orders to suppliers, and $53.7 \%$ of respondents use the internet for product and market research. In addition, 53.4\% of the respondents use the website technology to offer information to customers while $53.1 \%$ of respondents use the company website to receive orders from customers. It is also seen from the results that, $36.1 \%$ of the respondents were able to offer online payments options using the Internet.

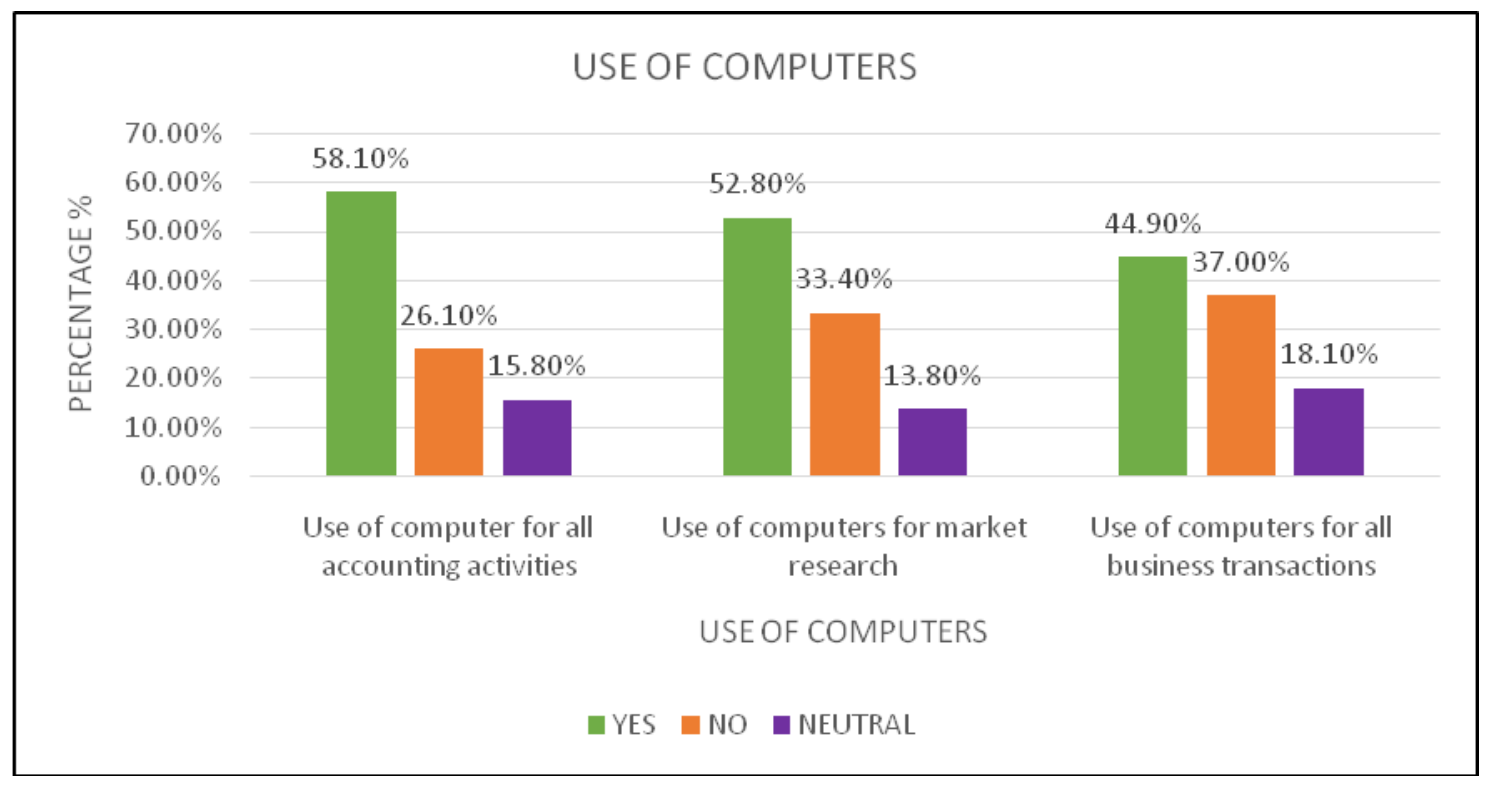

Figure 2: Use of Computers

\section{Post-Adoption Performance Evaluation}

Performance measures looked at in this study includes profit, market size and the ability of firms to innovate. Analysis result are summarized in Figure 4. Results show that, $49.6 \%$ of the surveyed firms attributed their profit to computer adoption and $44.9 \%$ of the surveyed firms attributed their profit rise to internet adoption. In terms of increase of market share due to ICT adoption, $47.5 \%$ of the firms attributed their market share increase to computer adoption, while $48.1 \%$ of the surveyed firms attributed their market share increase to internet adoption. In addition to the market share, $53.4 \%$ of the firms recoded the emergence of new processes that enhance efficiency (Process Innovation) due to computer adoption while $48.7 \%$ of the surveyed firms attributed their process innovation to internet adoption. 


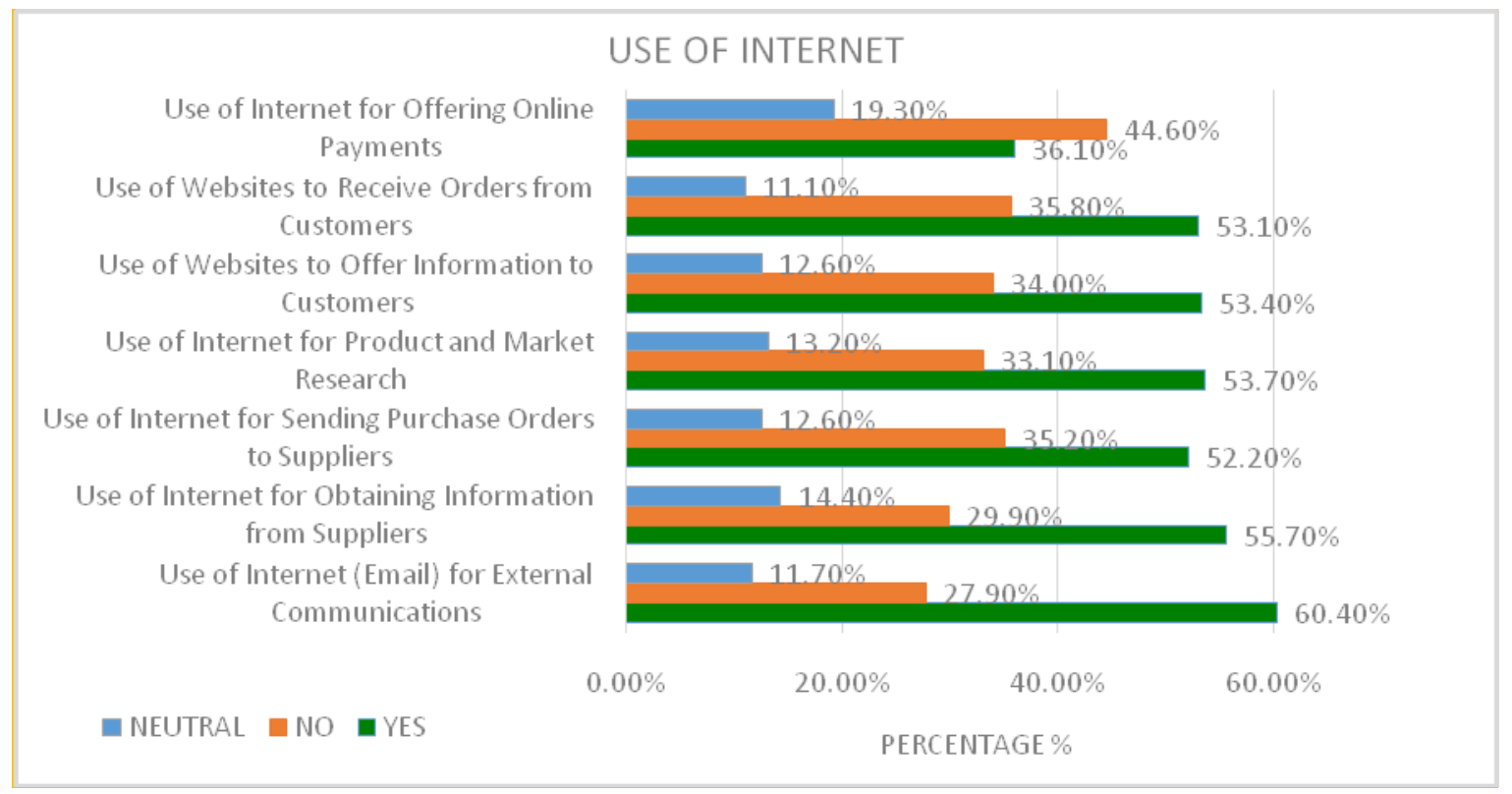

Figure 3: Use of the Internet

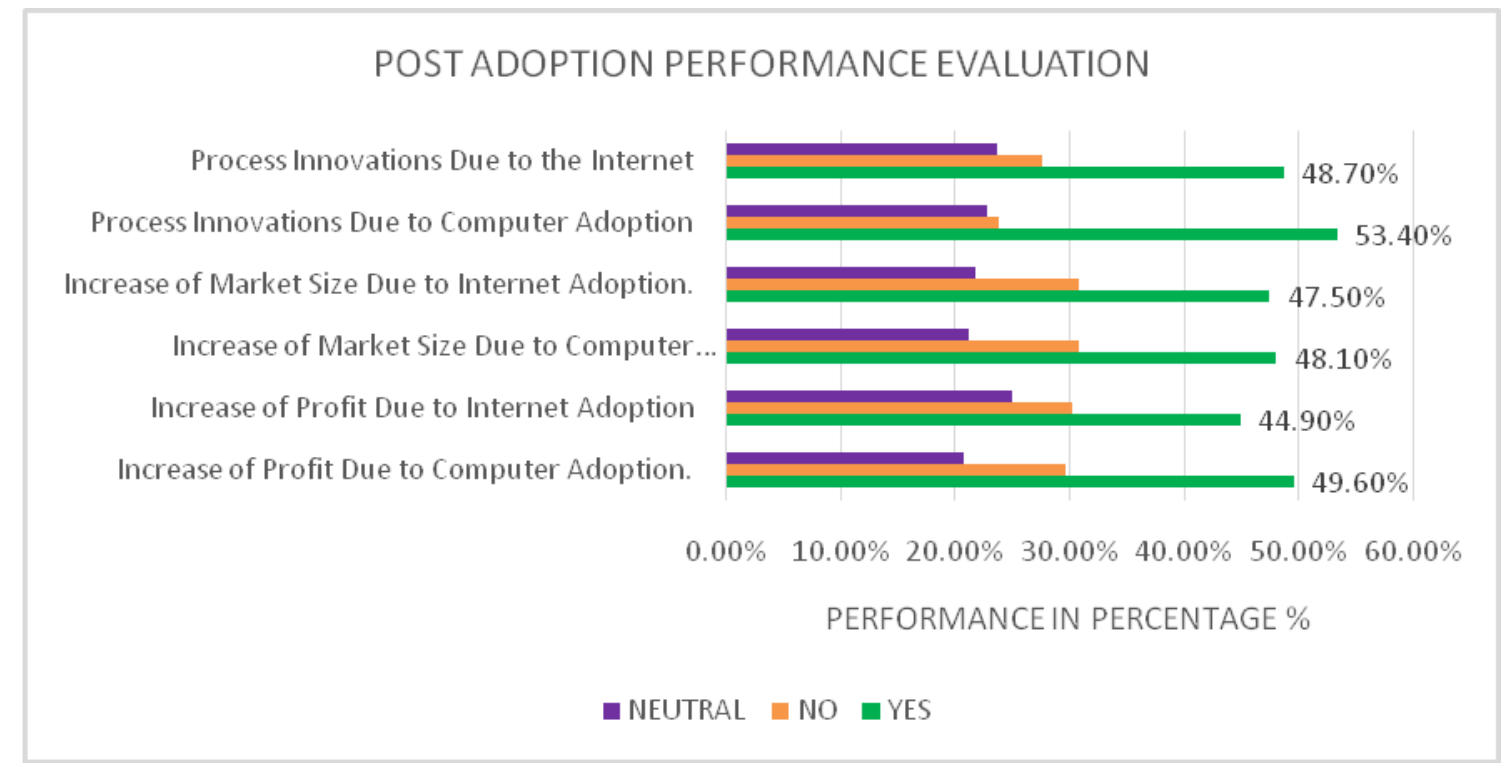

Figure 4: Post Adoption Performance Evaluation

\section{DISCUSSION}

From the observations made, contrary to the data presented by the literature prior to commencement of this study, (Jonathan, 2004; Mbamba, 2004; Muttayabalwa, 2007; Souter et al., 2007; Issaya, 2009; Behitsa et al., 2010; Naul, 2012; URT, 2012) which showed very low usage of ICTs in Tanzania SMEs, the findings of these analyses show that, by year 2014, computer adoption by SMEs in the service and trading sector had reached $80.1 \%$, internet adoption had reached $68.9 \%$, website adoption had reached $56.6 \%$, and email adoption had reached $72.7 \%$ as depicted by Figure 1. These findings point to remarkable and rapid growth in adoption and usage of ICTs in Tanzania SMEs sector in the last decade. 
As pointed out earlier, adoption of ICTs in itself does not make the SMEs competitive (Modimogale, 2009) and that the competitiveness of the firm depends on how the ICTs are being utilised. Research findings regarding ICT use in Tanzania SMEs as depicted by Figure 2 show that, $58.1 \%$ of firms use computers to handle all accounting activities, $52.8 \%$ of firms use computers for market research and $44.9 \%$ of firms use computers for all business transactions. In addition, research results as depicted by Figure 3 show that, about $53 \%$ of the surveyed firm's use the ICTs in a manner consistent with using of the internet and web technologies as a strategic communication and marketing tool. This is supported by the fact that $53.7 \%$ of these firms were able to use company websites to conduct product and market research, $53.4 \%$ were able to offer product information to their customers, and $53.1 \%$ were able to receive orders from customers. On a similar note, it is observed from Figure 3 that, about $36.1 \%$ of the surveyed SMEs could offer online payment options. These observations confirm the strategic use of ICTs by some SMEs and the emergence of e-commerce within the SME sector in Tanzania.

Post adoption performance evaluation of the surveyed firms present evidence to the effect that by early 2014, about $48 \%$ of surveyed SMEs were innovative since the firms managed to achieve process innovation as depicted by Figure 4 . Further post adoption analyses show that, by early year 2014, about $47 \%$ of SMEs in Tanzania were using ICTs in a way that allowed the firms to gain competitive advantage. These firms acknowledged improved performance in terms of increase in profit and market size as a result of ICT adoption and use. (See Figure 4). This observation suggests that, for firms that are competitive, there is a positive and direct relationship between ICT adoption and SMEs performance.
On the other hand, it is also imperative to point out that, more than a half $(53 \%)$ of the SMEs that had adopted (See Figure 4) were not using ICTs in a productive way since they did not report any improvement in their performance despite having adopted ICTs. These observations augur well with the literature that competitiveness depends on how ICTs are used (Modimogale, 2009). A much closer look at the results (See Figure 4) show that, there are about $48 \%$ of firms that are innovative and about $47 \%$ of firms that are competitive. Thus, it can be said that, the majority $(53 \%)$ of SMEs in Tanzania are not using ICTs to gain competitive advantage because they are not innovative. This is major issue of concern since 53\% is quite significant.

\section{CONCLUSIONS}

Results of this study reveal that ICT adoption in Tanzania SMEs has risen from almost non-existent in year 2004 to $80.1 \%$ computer, $68.9 \%$ internet, $56.6 \%$ website, and $72.2 \%$ email (Figure 1) in just 10 years. It has also been discovered that, more than $53 \%$ of the SMEs were using ICTs as a strategic communication and marketing tool. In addition to that, $47 \%$ of the SMEs were found to competitive due to ICT adoption and use. Research results also show that, $53 \%$ of SMEs that had adopted ICTs are not using the technologies to their advantages.

These findings suggest that, the awareness of owners-managers on the benefits of ICTs to their businesses has risen in this period and that resulted in over 56\% adoption rate. On the other hand, results show that post adoption use of ICTs is an issue of great concern. $53 \%$ of the firms that had adopted were not innovative and thus not competitive. According to the literature, the problem may be due to a number of factors such as lack of qualified ICT personnel, lack of strategies for ICT 
implementations, poor business environment and or lack of finances. To determine the root course of the problem a follow up research need to be carried out.

\section{ACKNOWLEDGEMENT}

The authors acknowledge the financial support from University of Dar es Salaam Management through the UDSM SIDA SAREC project. Without this support this research could not have been possible. Moreover, the assistance from MIE Department and COET on issues related to this research is highly appreciated.

\section{NOMENCLATURE:}

GDP Gross Domestic Product

ICT Information and Communication Technology

IS Information Systems

IT Information Technology

SME Small and Medium Scale Enterprise

\section{REFERENCES}

Ahmed I., Shahzad A., Umar M. and Khilji B.A. (2010). Information Technology and SMEs in Pakistan. International Business Research, 3(4): 237 240.

Apulu I. and Ige E.O. (2011). Are Nigeria SMEs Effectively Utilizing ICT? International Journal of Business and Management, 6(6): 207 214.

Apulu I. (2012). Developing a Framework for Successful Adoption and Effective Utilisation of ICT by SMEs in Developing Countries: A Case Study of Nigeria. PhD Thesis, University of Wolverhampton.

Ashrafi R. and Murtarza M. (2010). ICT adoption in SME in an Arab GCC Country Oman, in: E-strategies for Resource Management systems: Planning and Implementation. IGI Global.
Beckinsale M. and Ram M. (2006). Delivering ICT to ethnic minority businesses: An action-research approach, Environment and Planning C: Government and Policy, 24(6): 847 867.

Behitsa M.M. and Diyamett B.D. (2010). Tanzania ICT Sector Performance Review 2009/2010, Towards Evidence-based ICT Policy and Regulation, Policy Paper 11, 2: $11 \sim 30$.

Consoli D. (2012). Literature analysis on determinant factors and the impact of ICT in SMEs, Procedia-Social and Behavioural Sciences, 62: 93-97.

Costello P. (2009). Towards a Model of ICT adoption for the ICT Cluster in the West Midlands. PhD Thesis, University of Wolverhampton, UK.

Department for Business Innovations and Skills (DBIS) (2013). SMEs: The Key Enablers of Business Success and Economic Rationale for Government Interventions. BIS Analysis, Paper no 2.

European Commission. SMEs Performance Review-Fact and figures about the EU's Small and Medium Enterprise (SME) (2014). Available online at: http://ec.europa.eu/enterprise/policies/ sme/facts-figuresanalysis/index_en.htm.

Evans E. and Wurster T. (1997). Strategy and the New Economics of Information, Harvard Business Review, September/October 1997, 71 83.

Frempong, G. (2007). Trends in ICT Usage by Small and Medium Scale Enterprises in Ghana, ATDF Journal, 4(1): 3 10.

Harindranath G., Romano D. and David B. ICT in small firms: Factors affecting the adoption and use of ICT in Southeast England SMEs, Royal Holloway, University of London, Egham, Surrey TW20 0EX.

International Finance Corporation. Scaling-Up SME Access to Financial 
Services in the Developing World, G20 Seoul Summit 2010, Financial Inclusion Experts Group, SME Finance Sub-Group, October 2010, Available at: www.gpfi.org/sites/default/files/docu ments/G20_Stocktaking_Report_0.pdf

Ion P. and Andreea, Z. Use of ICT in SMEs management within the sector of services. Available at: www.steconomice.uoradea.ro/anale/v olume/2008/v4-management marketing/085.pdf.

Isaya P. (2009). Assessment of the factors influencing adoption of e-business technology by SMEs in Tanzania. Masters of Business Administration (MBA) Dissertation, University of Dar es Salaam.

Jennex, M. E., Amoroso, D. and Adelakun, O. (2004). E-commerce infrastructure success factors for small companies in developing economies, Electronic Commerce Research, 4: 263-286.

Jonathan N. (2004). Role of ICTS for the Performance of SMES in Tanzania: A survey of Enterprises in Dar es Salaam City. Master of Business Administration (Marketing) Dissertation, University of Dar es Salaam.

Kartiwi M. and MacGregor, R.C. (2007). Electronic commerce Adoption Barriers in Small to Mediums Sized Enterprises (SMEs) in Developed and Developing countries: A crosscountry comparison, Journal of Electronic Commerce in Organizations, 5(3): 35 41.

Manueli, K., Latu, S., and Koh, D. (2007). ICT Adoption Models, Pro. 20th Annual Conference of the National Advisory Committee on Computing Qualifications (NACCQ), Nelson, New Zealand, pp.175-181. Available at: www.naccq.ac.nz.

Massawe, D. (2003). Role of Small and Medium Enterprises in Income Generation, a paper presented at
Kilimanjaro Investment Workshop, $14^{\text {th }}-15^{\text {th }}$ August, 2003.

Mbamba U.O.L. (2004). Problems of Information Management in Small and Medium Enterprises in Tanzania: Information System Success Perspective. PhD Thesis, Business Administration, University of Dare es Salaam Tanzania, 2004.

Mlingi B.A. (2000). State of the Art Review of the Informal Sector in Tanzania, 1990-1999, prepared for the International Labour Office.

Modimogale L. (2009). ICT and SMEs' Competitiveness in South Africa: How SMEs could use ICT to become competitive in South Africa. MSc. Thesis, University of Pretoria, South Africa.

Mpofu K.C., Milne D. and Watkin-Mathys L. (2009). ICT and Development of EBusiness among SMEs in South Africa, The Institute for Small Business and Entrepreneurship. Available online at: http://www.isbe.org.uk.

Muttayabalwa A.C. (2007). Assessment of the use of internet technology by service SMEs in Tanzania: the case of accounting firms in Dar es Salaam Region. Masters of Business Administration (MBA) Dissertation, University of Dar es Salaam.

Naul, G. (2012). Assessment of the usage of ICT in Small and Medium Enterprises (SMES) Development: The Case of Dar es Salaam Region. Masters of Business Administration (MBA) Dissertation, University of Dar es Salaam.

National Bureau of Statistics (NBS) Tanzania.Integrated labour force survey: key findings report, Ministry of Labour, Youths Developments and Sports, Tanzania, 2014. Available at: http://labordoc.ilo.org/search?p=4819 $\underline{99}$.

National Informal Sector Survey(NISS) (1991). Unpublished report, Planning Commission and Ministry of Labour, 
United Republic of Tanzania (URT), Dar es Salaam.

OECD Oslo manual (2005). The Measurement of Scientific and Technological Activities: Proposed Guidelines for Collecting and Interpreting Technological Innovation Data. Available online at: www.oecd.org/science/inno 12367580.pdf

Olomi D.R. (2005). Position Paper On Enhancing SME's Access to Government Procurement and Food Standards. Presented at The Stakeholder Workshop, Regency Park Hotel, Dar Es Salaam, 30 ${ }^{\text {th }}$ September 2005, University of Dar es Salaam Entrepreneurship Centre.

Olomi D.R. (2006). Policy Dialogue Seminar Paper on Opportunities and Challenges for Rural SMEs Development in Tanzania. Economic and Social Research Foundation (ESRP).

Olise M.C., Anigbogu T.U., Edoko T.D. and Okoli M.I. (2014). Determinants of ICT Adoption for Improved SME's Performance in Anambra State, Nigeria, American International Journal of Contemporary Research, 4(7): 163 176.

Pass C.L., Bryan L., and Leslie D. (2000). Economics Dictionary, 3RD Ed, Harper Collins Publication.

Pavic S., Koh S.C.L., Simpson M. and Padmore J. (2007). Could e-business create a competitive advantage in UK SMEs? Benchmarking, 14(3): 320 351.

Souter D., Scott N., Garforth C., Jain R., Mascarenhas $\mathrm{O}$. and McKemey $\mathrm{K}$. (2007). The Economic Impact of Telecommunications on Rural Livelihoods and Poverty Reduction: A study of rural communities in India (Gujarat), Mozambique and Tanzania,
Report of DFID KaR Project 8347, pp 268-335. Available online at: www.telafrica.org/R8347/files/pdfs/Fi nalReport.pdf

Skoko H., and Arnela, C. (2010). Study on Information and Communication Technology (ICT) Models of Adoption and Use in the Kingdom of Saudi Arabian SMEs Alfaisal University, Riyadh, Kingdom of Saudi Arabia.

Sophonthummapharn K.A. (2008). Comprehensive Framework for the Adoption of Techno-Relationship Innovations: Empirical Evidence from eCRM in Manufacturing SMEs, Published $\mathrm{PhD}$ thesis submitted to Umeå School of Business, Umeå University.

Tarutė A. and Gatautis R. (2014). ICT impact on SMEs performance, Contemporary Issues in Business, Management and Education 2013. Procedia-Social and Behavioural Sciences, (C) 2014 The Authors. Published by Elsevier Ltd.

United Nations Development Programme (2007). The role of governments in promoting ICT access and use by SMEs: considerations for public policy, APDIP e-note. Available online at: www.apdip.net/apdipenote/12.pdf

United Republic of Tanzania (URT) (2012). Ministry of Trade and Industry. National Baseline Survey Report on Micro, Small, and Medium Enterprises in Tanzania, Dar es Salaam, December.

United Republic of Tanzania (URT). (URT) (2002). Tanzania Small and Medium Enterprise Development Policy. Available online at: http://www.mit.go.tz/uploads/docume nts/sw/1455890063-SMEDevelopment-Policy.pdf 